KOŚCIÓŁ I PRAWO 8(21) 2019, nr 2, s. 31-48

DOI: http://dx.doi.org/10.18290/kip.2019.8.2-2

\author{
Martyna Pereta
}

\title{
PRAWO DZIECKA DO WYCHOWANIA W PRAWODAWSTWIE KOŚCIOŁA ŁACIŃSKIEGO Z ELEMENTAMI PRAWA POLSKIEGO
}

Nie bez przyczyny wychowanie stanowi nie tylko prawo, ale i poważny obowiązek rodziców, którego nie mogą zaniechać bez naruszenia prawa. W Karcie Praw Rodziny przypomina się, że: „Wszystkie dzieci bez względu na to, czy narodziły się z małżeństwa, czy też ze związku pozamałżeńskiego, posiadają takie same prawa do opieki społecznej i troski o pełny rozwój ich osobowości"1. Zdarza się, że wadliwe wychowanie często uwarunkowane jest pewnego rodzaju patologiami, złymi warunkami bytowymi, a także brakiem odpowiedzialności rodziców za dziecko. Aktualnie spotyka się wyroki stwierdzające niezdolność mężczyzny lub kobiety do podjęcia istotnych obowiązków małżeńskich z przyczyn natury psychicznej, ponieważ w przeszłości rodzice nie wywiązywali się ze swoich obowiązków wychowawczych ${ }^{2}$. Powyższa kwestia uzasadnia konieczność podjęcia tematu przywołanego w tytule.

Mgr lic. Martyna Pereta - doktorant, Katedra Kościelnego Prawa Procesowego, Małżeńskiego i Karnego oraz Katolickich Kościołów Wschodnich, Instytut Prawa Kanonicznego, Wydział Prawa, Prawa Kanonicznego i Administracji Katolickiego Uniwersytetu Lubelskiego Jana Pawła II; adres do korespondencji: Al. Racławickie 14, 20-950 Lublin, Polska; e-mail: martynapereta@gmail.com; https://orcid.org/0000-0003-2501-6458

${ }^{1}$ Pontificium Consilium Pro Familia, Carta de familiae iura (22.10.1983), Enchiridion Vaticanum, nr 9, s. 538-52; tekst polski w: „L'Osservatore Romano” (wyd. pol.) 4 (1983), nr 10, s. 6-7, art. 4d.

${ }^{2}$ Szerzej zob. Paździor 1999, 195; Pastwa 2014, 48-64. 


\section{DZIECKO JAKO PODMIOT WYCHOWANIA}

W Kodeksie Prawa Kanonicznego z 1983 r. ${ }^{3}$ została ujęta definicja dziecka. W kan. $97 \S 2$ ustawodawca przyjmuje, że małoletniego przed ukończeniem siódmego roku życia uważa się za dziecko (infans) i osobę niezdolną do kierowania swoim postępowaniem (non sui compos). Istnieje domniemanie, że osoba małoletnia po ukończeniu siódmego roku życia jest w stanie kierować swoim postępowaniem [Pawluk 2002, 254]. Aczkolwiek, nie należy dopuszczać do składania zeznań małoletnich poniżej czternastego roku życia (kan. 1550 § 1). Przepisy prawa kanonicznego rozróżniają „dziecko” i „osobę małoletnią”. Można dostrzec zatem, że odnośnie do podmiotu wychowania brak jest jednak jednolitości terminologicznej [Krajczyński 2005, 165]. Ustawodawca w KPK/83 dla określenia podmiotu wychowania posługuje się zwrotami: wychowanie potomstwa (kan. $793 \S 1$, kan. 1136, kan. 1055 § 1), dziecko lub dzieci (kan. 226 § 2, kan. 793 § 1-2, kan. 798, kan. $868 \S 1,2^{\circ}$, kan. $1071 \S 1,3^{\circ}$, kan. $1125,1^{\circ}$, kan. 1154 , kan. 1366, kan. 1689), dzieci i młodzież (kan. $528 \S 1$, kan. 795) oraz wierni (kan. 794 § 2). Zdarza się, że w ogóle nie określa podmiotu wychowania (kan. $796 \S 1$, kan. 801, kan. $802 \S 1$, kan. 803 §, kan. $804 \S 1$ ). Niemniej jednak dziecko przez chrzest zostaje wcielone do Kościoła i staje się w nim osobą z obowiązkami i prawami, które są właściwe chrześcijanom (kan. 96). W świetle przepisów kodeksowych, dziecko nie jest zdolne do popełnienia przestępstwa (kan. 1323, $1^{\circ}$ i $6^{\circ}$ ). Po ukończeniu odpowiednio czternastu (kobieta) i szesnastu (mężczyzna) lat dziecko wchodzi w etap dojrzałości kanonicznej, lecz nadal pozostaje małoletnim. Od tego czasu dziecko uważane jest za dojrzałe psychicznie i fizycznie, ponieważ istnieje domniemanie zdolności do zrodzenia potomstwa (kan. $1083 \S 1$ ). Prawo kanoniczne reguluje również zagadnienie dzieci adoptowanych i zrównuje je w statusie z dziećmi naturalnymi (kan. 110). Spośród kanonów odnoszących się do małoletniego i jego uprawnień należy mieć na uwadze, że w określonych sprawach dotyczących prawa Bożego lub kanonicznego, są oni wyjęci spod władzy rodziców (kan. 98 §). To uprawnienie małoletniego można powiązać z kan. 1478 § 3 , który normuje zdolność procesową podmiotu wychowa-

${ }^{3}$ Codex Iuris Canonici auctoritate Ioannis Pauli PP. II promulgatus (25.01.1983), AAS 75 (1983), pars II, s. 1- 317; tekst polski w: Kodeks Prawa Kanonicznego, przekład polski zatwierdzony przez Konferencję Episkopatu, Pallottinum, Poznań 1984 [dalej cyt.: KPK/83]. 
nia po osiągnięciu czternastego roku życia oraz uprawnienie podmiotu do występowania przed sądem $\mathrm{w}$ sprawach duchowych lub innych $\mathrm{z}$ nimi złączonych [Czujek 2015, 428]. Z chwilą ukończenia przez dziecko osiemnastego roku życia przysługują mu pełne prawa i obowiązki (kan. $98 \S 1$ ).

Pomimo niejednolitości terminologicznej, dziecko od samego początku jest podmiotem wychowania. Cały proces wychowania zakłada uznanie jego podmiotowości, zrozumienie jego potrzeb, rozeznanie się w jego możliwościach, aby wspierać jego rozwój oraz traktować wychowanie jako służbę dziecku [Wilk i Bieleń 2006, 455]. Niezbędna do wychowania dziecka jest zatem atmosfera miłości, którą mogą stworzyć świadomi swoich obowiązków rodzice [Cader 2004, 9].

\section{PRAWO DZIECKA DO WYCHOWANIA}

Każdy człowiek posiada właściwą sobie przyrodzoną godność, a uznanie godności ludzkiej zakłada poszanowanie i ochronę jego praw. Spośród podstawowych praw człowieka, które zapewniają możliwość prowadzenia życia prawdziwie ludzkiego należy bez wątpienia wymienić prawo do wychowania ${ }^{4}$. Papież Pius XI w encyklice Divini illius Magistri zwracał się niejednokrotnie do rodziców, aby podjęli $\mathrm{z}$ większym zapałem swoje obowiązki, gdyż posiadają „bezpośrednio od Stwórcy posłannictwo, a stąd też i prawo wychowania potomstwa, prawo, którego zrzec się nie można, ponieważ nierozdzielnie łączy się ono ze ścisłym obowiązkiem". W adhortacji apostolskiej Familiaris consortio ${ }^{6}$ papież Jan Paweł II podkreślił, że dziecko powinno być otoczone szczególną troską. Należy zadbać o „głęboki szacunek dla jego godności osobistej oraz ze czcią i wielkodusznie służyć jego prawom” (nr 26). Szczególnie należy pamiętać o tym wobec „dziecka małego,

\footnotetext{
${ }^{4}$ Sacrosanctum Concilium Oecumenicum Vaticanum II, Declaratio de educatione Christiana Gravissimum educationis (28.10.1965), AAS 58 (1966), s. 728-39; tekst polski w: Sobór Watykański II, Konstytucje, dekrety, deklaracje. Tekst polski. Nowe tłumaczenie, Pallottinum, Poznań 2002, s. 314-24 [dalej cyt.: GE], nr 1.

${ }^{5}$ Pius PP. XI, Litterae encyclicae de christiana iuventutis educatione Divini illius Magistri (31.12.1929), AAS 22 (1930), s. 49-86; tekst polski w: Encykliki społeczne Kościoła katolickiego, Oficyna Wydawnicza ATUT, Świdnica 2005, s. 77-118, nr 32.

${ }^{6}$ Ioannes Paulus PP. II, Adhortatio apostolica de Familiae christianae muneribus in mundo huius temporis Familiaris consortio (22.11.1981), AAS 74 (1982), s. 81-191; tekst polski w: Jan Paweł II. Dzieła zebrane. T. 2: Adhortacje, Wydawnictwo „M,” Kraków 2006, s. 67-132.
} 
wymagającego opieki całkowitej, wobec dziecka chorego, cierpiącego lub upośledzonego" (nr 26). Papież Franciszek w adhortacji apostolskiej Amoris laetitia ${ }^{7}$ przypomina rodzicom, że mają poważny obowiązek „wypełniania swojej misji edukacyjnej”. Same dzieci wzywa się zaś do przyjęcia i praktykowania jednego z przykazań: „Czcij ojca twego i matkę twoją”. Czasownik „czcić” znaczy „wywiązywanie się w pełni ze zobowiązań rodzinnych i społecznych, nie zaniedbując ich przez uciekanie się do wymówek religijnych (por. Mk 7,11-13)" (AL 17).

Obowiązek wychowania dzieci znajduje swoje podstawy w prawie naturalnym oraz wynika z natury samego sakramentu małżeństwa [Stawniak 1993, 25]. Małżeństwo to przymierze „przez które mężczyzna i kobieta tworzą ze sobą wspólnotę całego życia, skierowaną ze swej natury do dobra małżonków oraz do zrodzenia i wychowania potomstwa" (kan. $1055 \S 1$ ). Rozumienie „skierowania” jako celu małżeńskiego pozwala nadać znaczenie prawne wszystkiemu, co owo skierowanie określa, czyli przede wszystkim obowiązku wychowania potomstwa [Cymbała 2002, 20]. Należy zaznaczyć, że gdyby wykazano, że dana osoba z racji awersji do dzieci nie jest zdolna podjąć obowiązku wychowania, to należałoby ją uznać za niezdolną do wyrażania prawdziwej zgody małżeńskiej [Sztychmiler 1998, 122]. Ustawodawca kodeksowy stwierdza wprost, iż: „Rodzice, ponieważ dali dzieciom życie, mają bardzo poważny obowiązek i prawo ich wychowania" (kan. $226 \S 2$, kan. $793 \S 1$ i kan. 1136). Rangę owej troski rodziców o wychowanie potomstwa prawodawca kodeksowy nazywa officium gravissimum [Pawluk 1984, 213]. Samo użycie tych terminów zdaje się jednocześnie wskazywać na gwarancję prawa dziecka do wychowania. Całościowe wychowanie dziecka powinno zawierać w sobie wkład rodzicielski, gdyż harmonijne zaangażowanie rodziców, to nic innego jak obecność matki i ojca [Stawniak 1989, 138].

Ustawodawca zabezpiecza prawo dziecka do wychowania poprzez szereg kanonów zawierających liczne zakazy, nakazy i pouczenia. Zakazuje się bez zezwolenia ordynariusza miejsca asystować przy małżeństwie osoby, którą wiążą naturalne obowiązki wobec dzieci, wynikające z poprzedniego związku (kan. $1071 \S 1,3^{\circ}$ ). Na szczególną uwagę zasługuje również

\footnotetext{
${ }^{7}$ Franciscus PP., Adhortatio apostolica post-synodalis de Amore in Familia Amoris laetitia (19.03.2016), AAS 108 (2016), s. 311-446; tekst polski: Ojciec Święty Franciszek, Posynodalna Adhortacja apostolska Amoris laetitia. O miłości w rodzinie, Wydawnictwo „M”, Kraków 2016 [dalej cyt.: AL].
} 
kan. $1691 \S 1$ motu proprio Mitis Iudex Dominus Iesus, który zaleca, aby w wyrokach o stwierdzenie nieważności małżeństwa przypominać stronom o ciążących na nich zobowiązaniach w kwestii utrzymania i wychowania potomstwa ${ }^{8}$. Wydaje się, że ustawodawca $\mathrm{w}$ ten sposób chce przypomnieć rodzicom dziecka, iż wyrok stwierdzający nieważność małżeństwa nie stanowi kontynuacji procedury rozwodowej, a wyroki sądów świeckich nie tworzą w systemie prawa kanonicznego norm generalnych i abstrakcyjnych. Niekiedy jednak mają wpływ na interpretację prawa kościelnego [Kroczek 2013, 72]. Zobowiązaniami, które wynikają przede wszystkim z ustawy Kodeks rodzinny i opiekuńczy ${ }^{9}$ mogą być kwestie dotyczące utrzymania dziecka - alimenty (art. 128), obowiązek zatroszczenia się o wychowanie dziecka (art. $95 \S 1$, art. $96 \S 1$, art. $97 \S 1$ ) i utrzymywanie przez rodziców kontaktów z dzieckiem (art. $113 \S 1$ ). Podobnie z chwilą podjęcia przez małżonków decyzji o separacji, powinni oni zatroszczyć się o odpowiednie utrzymanie i wychowanie swoich dzieci (kan. 1154 KPK/83).

Współdziałanie małżonków mających na celu budowanie poprawnych i głębokich relacji interpersonalnych, podejmowanie wspólnie trudów, stanowi szansę zarówno dla nich samych, jak i dla ich potomstwa. Ponadto niczym niezakłócone współdziałanie małżonków jest fundamentem realizacji obowiązków związanych z prawem dziecka do wychowania w rodzinie [Czujek 2015, 438]. Nie należy zatem rozpatrywać prawa dziecka do wychowania w oderwaniu od praw i obowiązków rodziców w zakresie wychowania potomstwa.

\section{PRAWO DZIECKA DO WYCHOWANIA W MAEŻEŃSTWACH MIESZANYCH}

Mogłoby się wydawać, że największe zagrożenie dla gwarancji prawa dziecka do wychowania stanowią małżeństwa mieszane. Definicja „mał-

\footnotetext{
8 Tenże, Litterae apostolicae motu proprio Mitis Iudex Dominus Iesus quibus canones Codicis Iuris Canonici de Causis ad Matrimonii nullitatem declarandam reformatur (15.08.2015), AAS 107 (2015), s. 958-67; tekst polski: Franciszek, List apostolski motu proprio Mitis Iudex Dominus Iesus reformujący kanony Kodeksu Prawa Kanonicznego dotyczące spraw o orzeczenie nieważności małżeństwa (tekst łacińsko-polski), Wydawnictwo Diecezji Tarnowskiej Biblos, Tarnów 2015, s. 4-45.

${ }^{9}$ Ustawa z dnia 25 lutego 1964 r. Kodeks rodzinny i opiekuńczy, Dz. U. z 2019 r., poz. 2086
} 
żeństwa mieszanego” została zawarta w kan. 1124 KPK/83: „Małżeństwo między dwiema osobami ochrzczonymi, z których jedna została ochrzczona w Kościele katolickim lub po chrzcie została do niego przyjęta i formalnym aktem od niego się nie odłączyła, druga zaś należy do Kościoła lub wspólnoty kościelnej nie mającej pełnej łączności z Kościołem katolickim, jest zabronione bez wyraźnego zezwolenia kompetentnej władzy”. Dyrektorium ekumeniczne z 1993 r. zaleca, aby sugerować i popierać dyskusję oraz (jeśli jest to możliwe) decyzję podjętą przed zawarciem małżeństwa, na temat chrztu oraz katolickiego wychowania swoich dzieci (nr 150) ${ }^{10}$. Kościół zachęca zatem do trudnych dyskusji na temat przyszłości potomstwa i kierunku jego wychowania ${ }^{11}$. W tym miejscu należy wyjaśnić, że uszanowanie wolności religijnej drugiego małżonka polega na tym, iż „rodzic katolicki uznaje wolność religijną i sumienie drugiego rodzica oraz będzie się troszczył o jedność i trwałość małżeństwa i o zachowanie komunii rodzinnej. Jeżeli pomimo tych wszystkich wysiłków dzieci nie zostaną ochrzczone w Kościele katolickim rodzic katolicki nie popada pod cenzurę prawa kanonicznego. Nie mniej spoczywający na nim obowiązek dzielenia ze swymi dziećmi wiary katolickiej bynajmniej nie ustaje" (DE 151). Powyżej zasygnalizowane akcenty nie mogą przysłonić tego, że kościelny porządek prawny nakłada na małżonków (rodziców) liczne obowiązki w zakresie wychowania potomstwa. W kan. $1125,1^{\circ}$ jawi się kwestia złożenia przyrzeczenia, które składa strona katolicka, „że uczyni wszystko, co w jej mocy, aby wszystkie dzieci zostały ochrzczone i wychowane w Kościele katolickim”. Wątpliwości zatem dostarcza zobowiązanie, które musi złożyć drugi nupturient. Konferencja Episkopatu Polski w Instrukcji o przygotowaniu do zawarcia małżeństwa ${ }$ Kościele katolickim ${ }^{12}$, podkreśla że: „Kościól jest niechętnie nastawiony do małżeństw mieszanych i dlatego należy młodych od tych małżeństw odwodzić” (nr 73). Argumentacja dotyczy kwestii składania oświadczeń. „W wypadku, gdy strona niekatolicka, przyjąwszy do wiadomości zobowiązania strony katolickiej, wyraźnie by oświadczyła, że zrobi wszystko, by nie dopuścić do realizacji jej przyrzeczeń, dusz-

${ }^{10}$ Pontificium Consilium ad Unitatem Christianorum Fovendam, Directorium Oecumenicum noviter compositum (25.03.1993), AAS 85 (1993), s. 1093-119 [dalej cyt.: DE].

${ }^{11}$ Szerzej zob. Adamowicz 2014, 65-80.

${ }^{12}$ Konferencja Episkopatu Polski, Instrukcja o przygotowaniu do zawarcia małżeństwa w Kościele katolickim (13.12.1989), w: Dokumenty duszpastersko-liturgiczne Episkopatu Polski 1966-1993, red. Cz. Krakowiak, L. Adamowicz, Lubelskie Wydawnictwo Archidiecezjalne, Lublin 1994, s. 151-227. 
pasterz wyjaśni ze spokojem, że małżeństwo, które zamierzają zawrzeć, ma być wspólnotą ich życia i miłości wobec Boga, który dla wierzących jest najwyższą wartością. Dzieci zaś, które są darem Boga, dawcy życia, mają pogłębiać ich wspólnotę i uszlachetniać ją. Kościół katolicki chce udoskonalić wszystkie wartości ludzkie i dlatego też zawiązującego się ogniska rodzinnego nie można wystawiać na sytuację konfliktową zanim ono się ukształtowało” ( $\mathrm{nr}$ 86). Dodaje: „Gdyby strona katolicka nie chciała dostosować się do przepisu kan. 1125, n. 1 i odmówiła oświadczenia i przyrzeczenia według podanej tam treści, mimo otrzymanych pouczeń i wyjaśnień na ten temat, duszpasterz zaniecha starania się o zezwolenie, gdyż zobowiązania stawiane przez Kościół katolikowi, przy zawieraniu małżeństwa mieszanego, są świętym wymogiem wiary i prawa kościelnego. Episkopat Polski przypomina, że udzielanie dyspens i zwolnień nie jest tylko aktem usuwającym zakaz prawa do zawarcia małżeństwa, ale jest także okazaniem zaufania. Kościół pragnie, by zawiązujące się małżeństwo było błogosławionym znakiem Bożego pokoju i jedności w społeczeństwie” (nr 87). Na szczególną uwagę zasługuje również Instrukcja Episkopatu Polski w sprawie duszpasterstwa małżeństw o różnej przynależności kościelnej ${ }^{13}$. Instrukcja wskazuje na niebezpieczeństwo, jakie za sobą niesie wychowanie dzieci w różnych wyznaniach: „Wychowanie jednego dziecka w jednym wyznaniu a drugiego $\mathrm{w}$ innym byłoby utrwaleniem podziału wyznaniowego w rodzinie; łatwo też mogłoby się stać podłożem indyferentyzmu. Dlatego Kościół katolicki żąda od swych wiernych przyrzeczenia, że dołożą wszelkich starań, by wszystkie dzieci w ich małżeństwie były ochrzczone i wychowane w wierze katolickiej" (nr V.1.a). KEP przypomina, że w przypadku, gdyby „strona niekatolicka nie respektowała zobowiązań strony katolickiej, strona katolicka powinna zrobić wszystko, co w jej mocy, by dobro wiary dziecka nie poniosło uszczerbku" (nr V.1.b). Zakaz zawierania małżeństwa mieszanego może zostać zniesiony na skutek zaistnienia „słusznej i rozumnej przyczyny". Zezwolenie takie udziela ordynariusz miejsca (kan. 1125).

Sprawa związana z zawieraniem małżeństw przez katolików z tzw. osobami niegodnymi również została otoczona szczególną troską Kościoła. Przez osoby niegodne rozumie się osoby, które zostały ochrzczone w Ko-

${ }^{13}$ Taż, Instrukcja Episkopatu Polski w sprawie duszpasterstwa małżeństw o różnej przynależności kościelnej (14.03.1987), w: Dokumenty duszpastersko-liturgiczne Episkopatu Polski, s. 247-62. 
ściele katolickim, a później z niego wystąpiły formalnym aktem woli i są uważanie za osoby niewierzące i zwalczające Kościół [Sztafrowski 1985, 123-24]. W przypadku zawarcia małżeństwa przez stronę katolicką z osobami niegodnymi wymaga się zobowiązania strony katolickiej (takiej jak przy zawieraniu małżeństwa mieszanego) oraz zobowiązania drugiej strony, która oświadczy m.in., że nie będzie sprzeciwiać się wychowaniu potomstwa w wierze Kościoła katolickiego [Góralski, 2000, 156].

Należy podkreślić, że duży wpływ na prawo dziecka do wychowania w duchu chrześcijańskim ma strona katolicka. Wśród istniejących zagrożeń dotyczących wychowania potomstwa (w duchu katolickim) można wymienić sytuację, gdy małżonek akatolicki nie może zrealizować przyrzeczenia ze względu na swoją wiarę lub dominującą jego osobowość w związku. Taki typ małżonka zwykle „narzuca” swoją religię rodzinie lub decyduje, że dzieci nie zostaną wychowane w duchu żadnej religii. Zabezpieczeniem prawa dziecka do wychowania w takich sytuacjach może się okazać instytucja separacji. Jeżeli jedno z małżonków wychowuje dzieci w duchu akatolickim (dając tym samym zły przykład) i utrudnia wychowanie religijne potomstwa, drugi współmałżonek katolicki ma podstawy do żądania separacji w celu ochrony swojego obowiązku do katolickiego wychowania potomstwa (kan. 1153 KPK/83). Niemniej jednak należy szukać rozwiązań już na etapie przedślubnym, aby nie dopuszczać do takich sytuacji w przyszłości.

\section{ZAKRES PRAWA DZIECKA DO WYCHOWANIA}

Ustawodawca kodeksowy podkreślił, że proces wychowawczy powinien przebiegać $\mathrm{w}$ sposób harmonijny. Przede wszystkim powinien obejmować wychowanie: fizyczne, społeczne, kulturalne oraz moralne i religijne (kan. 1136). Wychowanie moralne jest stawiane obok wychowania religijnego. W Kodeksie Prawa Kanonicznego z 1917 r. ${ }^{14}$ ustawodawca podkreślał, że najważniejszym obowiązkiem rodziców jest wychowanie religijne i moralne, a następnie fizyczne i cywilne (kan. 1113). Ustawodawca tym samym wyodrębnił dwie sfery życia dziecka. Rodzice z jednej strony

\footnotetext{
${ }^{14}$ Codex Iuris Canonici Pii X Pontificis Maximi iussu digestus Benedicti Papae XV auctoritate promulgatus (27.05.1917), AAS 9 (1917), pars II, s. 1-593.
} 
muszą zatroszczyć się o rozwój fizyczny, a z drugiej duchowy swojego potomstwa.

Mówiąc o wychowaniu fizycznym dziecka należy podkreślić, że to właśnie na rodzicach spoczywa troska o to, aby od chwili poczęcia zostało zrodzone i rozwijało się w sposób prawidłowy. Rodzice poprzez wychowanie fizyczne powinni przygotować swoje potomstwo do życia w społeczności oraz nauczyć je komunikowania się z innymi grupami żyjącymi w społeczeństwie (GE 1). Dziecko musi mieć świadomość, że nie będzie prowadziło życia w pojedynkę, ale w społeczeństwie, w którym będzie korzystało z dobrodziejstw życia społecznego [Pawluk 1984, 214-15].

Kolejnym elementem procesu wychowawczego jest wychowanie kulturalne. Poprzez wychowanie kulturalne rodzice obowiązani są zapewnić swoim dzieciom odpowiednie wykształcenie, które ma za zadanie doprowadzić do pełnego rozwoju intelektualnego [Cymbała 2002, 61].

Nie można pominąć wychowania moralnego dziecka. Wychowanie moralne polega na kształtowaniu sumienia dziecka i pobudzaniu go do oceny wartości moralnych, które przejawiają się na płaszczyźnie dokonywania osobistych wyborów i przyjęcia ich za własne [Stawniak 2007, 34-35].

Prawdziwe wychowanie powinno obejmować pełną formację dziecka, aby mogło rozwijać swoje przymioty fizyczne, intelektualne oraz moralne, a także nabywać coraz lepszy zamysł odpowiedzialności, dzięki rozwinięte$\mathrm{mu}$ poczuciu sprawiedliwości społecznej (kan. $795 \mathrm{KPK} / 83$ ). Celowo w wyliczeniu zostało pominięte wychowanie religijne, gdyż wymaga ono odrębnego omówienia.

\section{PRAWO DZIECKA \\ DO CHRZEŚCIJAŃSKIEGO WYCHOWANIA}

Dziecko zrodzone z rodziców katolickich ma prawo do chrześcijańskiego wychowania z ich strony (kan. $217 \mathrm{KPK} / 83$ ). Sobór Watykański II potwierdził: „Wszyscy chrześcijanie cieszą się prawem do wychowania chrześcijańskiego zmierzającego nie tylko do pełnego rozwoju osoby ludzkiej, lecz przede wszystkim do stopniowego wprowadzenia ochrzczonych $\mathrm{w}$ tajemnicę zbawienia" (GE 2). W zakresie wychowania religijnego obowiązkiem rodziców jest wprowadzić dziecko w życie sakramentalne, które ma swój początek w sakramencie wtajemniczenia chrześcijańskiego. Sakrament 
chrztu stanowi bramę sakramentów i jest konieczny do zbawienia (kan. $849)^{15}$. Dzieci nie mogą osobiście wyrazić wiary ani mówić we własnym imieniu. W ich imieniu mówią rodzice, a wszystkie dzieci należy uznać za równe i ochrzcić zgodnie z prawem ${ }^{16}$. Dlatego też rodzice są zobowiązani do ochrzczenia dziecka jak najszybciej (kan. 867). Kościół sprzeciwia się praktyce zaniedbywania i bezpodstawnego opóźniania chrztu dziecka przez rodziców (PA 14). Na rodzicach ciąży obowiązek, aby z prośbą o chrzest dziecka zwrócić się do odpowiedniego szafarza. Zgodnie z KPK/83 zwyczajnym szafarzem chrztu jest biskup, prezbiter i diakon (kan. $861 \S 1$ ). W sytuacji naglącej rodzice powinni prosić o chrzest osobę, która spośród dostępnych osób najlepiej potrafi ochrzcić ich dziecko. Na pierwszym miejscu wymienia katechistę albo inną osobę, która jest wyznaczona do udzielenia chrztu przez ordynariusza miejsca, a w dalszej kolejności pozostałe osoby (kan. $861 \S 2$ ). Zgodnie z kan. $785 \S 1$ za katechistę uważa się osobę, która powinna być odpowiednio przygotowana i wyróżniająca się życiem chrześcijańskim. Gdyby w niebezpieczeństwie śmierci dziecka nie było takiej osoby, to jedno z rodziców może osobiście ochrzcić dziecko, gdyż ustawodawca nie wspomina o takim zakazie ${ }^{17}$. Do obowiązków rodziców należy również troska o to, by ich dziecko zostało ochrzczone ważnie i godziwe. Zadaniem rodziców jest zatem przedstawić do chrztu dziecko żywe, które nie zostało jeszcze ochrzczone (kan. 864). Jeżeli nie ma pewności czy dziecko żyje, chrztu należy udzielić warunkowo, o ile dziecko dotychczas nie zostało ochrzczone. Dlatego ścisłym obowiązkiem rodziców jest troska o to, aby dziecko przyjęło chrzest przed ewentualnym niebezpieczeństwem utraty życia. Może jednak zaistnieć sytuacja, w której fakt życia dziecka lub udzielenia chrztu są wątpliwe. Należy zatem tę wątpliwość usunąć poprzez staranne dochodzenie, a jeżeli wątpliwości nie da się usunąć, należy ochrzcić dziecko warunkowo (kan. 869 § 1). Określenie „warunkowo” ma tu znaczenie wyłącznie informacyjne, ponieważ ważność sprawowanego obrzędu zależy od tego, czy w przeszłości dana osoba została ważnie ochrzczona. Jeśli ten warunek nie zostanie spełniony, skuteczny jest

\footnotetext{
${ }^{15}$ Szerzej zob. Hemperek 1986, 76-77.

${ }^{16}$ Sacra Congregatio pro Doctrina Fidei, Instructio Pastoralis actio de baptismo parvulorum (20.10.1980), AAS 72 (1980), s. 1137-156 [dalej cyt.: PA]; tłumaczenie polskie: https://opoka.org.pl/biblioteka/W/WR/kongregacje/kdwiary/zbior/t_1_42.html [dostęp: 27.10.2019], nr 5 .

${ }^{17}$ Szerzej zob. Sztychmiler 1992, 176.
} 
warunkowy chrzest [Adamowicz 1999, 73]. Obok warunków ważności chrztu rodzice dziecka mają obowiązek zadbać, aby chrzest dziecka był godziwy. Do godziwości chrztu wymaga się zgody rodziców lub przynajmniej jednego z nich, albo podmiotów, którzy ich prawnie zastępują (kan. $868 \S 1,1^{\circ}$ ). Papież Franciszek na mocy motu proprio De Concordia inter Codices z dnia 31 maja 2016 r. zreformował kan. $868 \S 1,2^{\circ}$ i dodał $\S 3^{18}$. Takie uregulowanie jest konsekwencją troski ustawodawcy o zagwarantowanie pełnego wychowania katolickiego dzieci. Poważne wątpliwości budzi kan. $868 \S 2$, w którym ustawodawca kościelny stanowi: „Dziecko rodziców katolickich, a nawet i niekatolickich, znajdujące się w niebezpieczeństwie śmierci, jest godziwie chrzczone, nawet wbrew woli rodziców”. Przedmiotowa norma stanowiła przedmiot krytyki w doktrynie ${ }^{19}$. Niemniej jednak norma ta dalej obowiązuje $\mathrm{w}$ prawie kanonicznym i stanowi zabezpieczenie prawa dziecka do otrzymania sakramentu chrztu i dalszego wychowania.

\section{PRZYNALEŻNOŚĆ OBRZĄDKOWA DZIECKA}

Na szczególną uwagę zasługuje kwestia przynależności obrządkowej dziecka. Warto podkreślić, że kan. 111-112 KPK/83 zostały zreformowa$\mathrm{ne}^{20}$. Istotne znaczenie dla przynależności obrządkowej dziecka ma zgoda

\footnotetext{
${ }^{18}$ Papież Franciszek znowelizował kan. $868 \S 1,2^{\circ}$ a także dodał $\S 3$. Do godziwego ochrzczenia dziecka wymaga się: „,2 $2^{\circ}$ aby istniała uzasadniona nadzieja, że dziecko będzie wychowane po katolicku, z zachowaniem $\S 3$; jeśli jej zupełnie nie ma, chrzest należy odłożyć zgodnie z postanowieniami prawa partykularnego, powiadamiając rodziców o przyczynie”. „§ 3. Dziecko chrześcijan niekatolików jest godziwie chrzczone, jeśli o to proszą rodzice lub przynajmniej jedno z nich, albo ten, który ich zgodnie z prawem zastępuje, i jeśli fizycznie lub moralnie niemożliwe jest dotarcie przez nich do własnego szafarza”. Zob. Franciscus PP., Litterae apostolicae motu proprio datae quibus nonnullae normae Codicis Iuris Canonici immutantur De concordia inter Codices (31.05.2016), AAS 108 (2016), s. 602-606 [dalej cyt.: De concordia]; tłumaczenie polskie: http://archi walna.diecezja.pl/duchowni-i-konsekrowani/listy-i-dekrety/zmiany-w-kodeksie-prawa-ka nonicznego-dokonane-przez-papieza-franciszka-wmotu-proprio-de-concordia-inter-codices -z-dnia-31-05-2016-r-opublikowanego-w-dniu-15-09-2016-r-.html [dostęp: 27.10.2019], art. 4 i 5.

${ }^{19}$ Szerzej na temat chrztu dziecka wbrew woli rodziców zob. Zubert 1996, 34-64.

${ }^{20}$ Reformie uległ kan. 111: „§ 1. Do Kościoła łacińskiego zostaje włączone przez przyjęty chrzest dziecko rodziców, którzy do niego należą, lub - jeżeli jedno $\mathrm{z}$ nich do niego nie należy - którzy wyrazili zgodne życzenie, by potomstwo było ochrzczone w Kościele
} 
rodziców, która jest ograniczona ich własną przynależnością do wspólnoty religijnej. Zagrożenie dla prawa dziecka do wychowania może stanowić problem „wystąpienia z Kościoła” dzieci znajdujących się pod władzą rodzicielską. Dziecko nie może podjąć takiej decyzji przy sprzeciwie rodziców, jeżeli nie ukończyło czternastego roku życia [Adamowicz 2015, 27-28]. W takim przypadku dziecko nie podlega żadnej karze, jeżeli nie ukończyło szesnastego roku życia (kan. 1323, $1^{\circ}$ ). Należy podkreślić, że przepisy prawa kanonicznego zawierają kary dla rodziców, którzy nienależycie wykonują swoje obowiązki wychowawcze i naruszają prawo dziecka do wychowania. Rodzice (lub osoby ich zastępujące), którzy oddają dzieci do chrztu lub na wychowanie w religii niekatolickiej, powinni być ukarani cenzurą lub inną sprawiedliwą karą (kan. 1366). Stroną podmiotową przestępstwa są rodzice (ojciec, matka) i podmioty, które ich zastępują (w rozumieniu jak najszerszym, np. rodzina adopcyjna) [Syryjczyk 198, 223-25].

Analiza kanonów odnoszących się do przynależności obrządkowej na podstawie KPK/83 nie budzi wątpliwości. Należy jednak zaznaczyć, że rozważając przynależność obrządkową dziecka według Kodeksu Kanonów Kościołów Wschodnich ${ }^{21}$ można zauważyć, że regulacja tego Kodeksu dość

łacińskim; jeżeli zaś brak zgodności, zostaje włączone do Kościoła sui iuris, do którego należy ojciec. § 2 . Jeżeli zaś tylko jedno z rodziców jest katolikiem, zostaje włączone do Kościoła, do którego należy rodzic, który jest katolikiem. § 3 . Każdy z mających być ochrzczonym, który ukończył czternasty rok życia, może w sposób wolny wybrać chrzest w Kościele łacińskim lub w innym Kościele sui iuris; w takim wypadku należy do tego Kościoła, który wybrał”. Kan. 112: „§ 1. Po przyjętym chrzcie, do innego Kościoła sui iuris zostają włączeni: $1^{\circ}$ ten, kto otrzymał zezwolenie Stolicy Apostolskiej; $2^{\circ}$ małżonek, który - zawierając małżeństwo lub w czasie jego trwania - oświadczył, że pragnie przejść do Kościoła sui iuris drugiego małżonka; po rozwiązaniu jednak małżeństwa może w sposób nieskrępowany powrócić do Kościoła łacińskiego; $3^{\circ}$ dzieci tych, o których w nn. 1 i 2 , przed ukończeniem czternastego roku życia, a w małżeństwie mieszanym dzieci strony katolickiej, która zgodnie z przepisami prawa przeszła do innego Kościoła sui iuris; po osiągnięciu wskazanego wieku mogą powrócić do Kościoła łacińskiego. § 2. Nawet długotrwały zwyczaj przyjmowania sakramentów według obrzędów innego Kościoła sui iuris, nie pociąga za sobą włączenia do tego Kościoła. § 3 . Każde przejście do innego Kościoła sui iuris osiąga skutek z chwilą złożenia oświadczenia wobec ordynariusza miejsca tego Kościoła albo wobec własnego proboszcza lub delegowanego przez jednego z nich kapłana i dwóch świadków, chyba że reskrypt Stolicy Apostolskiej stanowiłby inaczej; winno być także odnotowane w księdze ochrzczonych". Zob. De concordia, art. 1 i 2.

${ }^{21}$ Codex Canonum Ecclesiarum Orientalium auctoritate Ioannis Pauli PP. II promulgatus (18.10.1990), AAS 82 (1990), s. 1045-363; tekst polski w: Kodeks Kanonów Kościołów Wschodnich promulgowany przez papieża Jana Pawła II, tłum. L. Adamo- 
szczegółowo normuje tę kwestię w porównaniu do Kodeksu łacińskiego. Zgodnie z kan. 29 § $1 \mathrm{KKKW}$ „Dziecko, które nie ukończyło czternastu lat, przez chrzest nabywa przynależność do Kościoła sui iuris, do którego należy jego ojciec katolik”. Natomiast jeżeli tylko matka jest katoliczką lub „oboje rodzice zgodnie dobrowolnie o to proszą, dziecko nabywa przynależność do tego Kościoła sui iuris, do którego należy jego matka, z zachowaniem prawa partykularnego zatwierdzonego przez Stolicę Apostolską”. Zgodnie z kan. 29 § 2 KKKW dziecko, które nie ukończyło czternastego roku życia, jest dzieckiem matki niezamężnej, nabywa przynależność do Kościoła sui iuris, do którego należy matka $\left(1^{\circ}\right)$. Natomiast jeżeli dziecko pochodzi od nieznanych rodziców, nabywa przynależność do Kościoła sui iuris, do którego należą ci, którzy prawnie sprawują nad nim opiekę. W przypadku sprawowania opieki przez rodziców adopcyjnych stosuje się normę z $§ 1$. Dziecko rodziców nieochrzczonych nabywa przynależność do Kościoła sui iuris, do którego należą ci, którzy przyjęli na siebie obowiązek wychowania go w wierze katolickiej $\left(3^{\circ}\right)$.

W KPK/83 brak jest analogicznych kanonów. Powyższy kanon regulujący kwestie międzyobrządkowe wiąże także w takich sytuacjach, w których jeden z małżonków należy do Kościoła łacińskiego [Adamowicz 2015, 26].

Kodeks reguluje zagadnienie przynależności obrządkowej dziecka i sankcje za lekceważenie obowiązku wychowania (oddawanie dzieci na wychowanie do rodzin niekatolickich). Warto wskazać, że w ustawodawstwie Kościoła łacińskiego brak jest działu traktującego wprost o prawach dziecka. Niemniej jednak należy uznać, że nie można przewidzieć zagrożenia, jakie przyjdzie $\mathrm{w}$ przyszłości uregulować $\mathrm{w}$ kanonicznym systemie prawnym. Idealnym zabezpieczeniem prawa dziecka do wychowania byłoby uregulowanie każdego przestępstwa, jakie można popełnić naruszając to prawo (w sposób pośredni i bezpośredni) dostosowując do każdego naruszenia adekwatną sankcję.

wicz, M. Dyjakowska, Wydawnictwo Archidiecezji Lubelskiej Gaudium, Lublin 2002 [dalej cyt.: KKKW]. 


\section{INSTYTUCJE ZABEZPIECZAJĄCE PRAWO DZIECKA DO WYCHOWANIA}

Rodzina nie jest w stanie sprostać wszystkim wymaganiom w zakresie wychowania potomstwa. W tym zakresie potrzebuje pomocy całej wspólnoty i różnych instytucji (kan. $793 \S 1 \mathrm{KPK} / 83$ ). Rodzice mają prawo do otrzymania ze strony państwa pomocy w zakresie wychowania katolickiego (kan. 793 § 2). Głównym zadaniem państwa jest wspomaganie rodziców w realizacji zadań wychowawczych tak, aby dzieciom zagwarantować katolickie wychowanie [Krukowski 2006, 53]. Do zadań państwa należy wspieranie wychowania dzieci (młodzieży) m.in. poprzez udzielanie wychowawcom pomocy, a w przypadku braku inicjatywy ze strony rodziców lub innych społeczności „dopełnienie dzieła wychowania zgodnie z zasadą pomocniczości” przy uwzględnieniu życzeń rodziców (GE 3). Zadanie państwa powinno polegać na odpowiedniej trosce „o taki podział subsydiów państwowych, aby rodzice mogli wybrać szkołę dla swych dzieci w sposób naprawdę wolny i zgodnie z sumieniem" (GE 6). Podobnie szkoły odgrywają ważną rolę $\mathrm{w}$ świadczeniu rodzicom pomocy w wypełnianiu ich obowiązków wychowawczych. Współdziałanie rodziców i nauczycieli wpływa na prawidłowe funkcjonowanie rodziny, harmonijny rozwój dziecka i warunkuje jego postępy w nauce. Szkoła samym rodzicom daje możliwość ciągłego doskonalenia się jako wychowawców odpowiedzialnych za prawidłowy rozwój dziecka [Świaczny i Pustelnik 2004, 42]. W tym miejscu trzeba zaznaczyć, że dzieci mają prawo, aby rodzice (podejmując decyzję o wyborze szkoły) posyłali je do szkół katolickich (kan. 798 i kan. 803). Szkoła powinna być miejscem współdziałania w religijnej formacji dzieci [Fiałkowski 2011, 384]. Rodzice, duszpasterze, katecheci, nauczyciele i wszyscy, którzy są zaangażowani w wychowanie dzieci powinni pamiętać, że najbardziej wiarygodną i skuteczną metodą wychowania jest osobisty przykład życia, uczciwe wypełnianie obowiązków, troska o ubogich, a także gorliwość apostolska [Krajczyński 2005, 117]. Obowiązkiem duszpasterzy jest czynić wszystko, aby wierni (również dzieci) mogli otrzymać należne im wychowanie (kan. $794 \S 2$ ). Ważne zadanie wychowawcze spoczywa na instytutach zakonnych, które powinny, za zgodą biskupa diecezjalnego, zakładać własne szkoły (kan. 801). 
Rodzice często zaniedbują swoje obowiązki wychowawcze obarczając odpowiedzialnością szeroko pojęte instytucje. Takie postępowanie należy uznać za naruszenie prawa dziecka do wychowania.

\section{ZAKOŃCZENIE}

Wszystkie dzieci $\mathrm{z}$ uwagi na przyrodzoną godność posiadają niezbywalne prawo do wychowania. Rodzice, ponieważ dali dzieciom życie, mają najcięższy obowiązek (gravissimum officium) wychowania potomstwa. Współcześnie z uwagi na ubóstwo rodziny, różnego rodzaju patologie, rodzice zapominają o swoich obowiązkach względem potomstwa. Prawo dziecka do wychowania zabezpieczają instytucje, których zadaniem jest wspieranie rodziców w wykonywaniu ich obowiązków wychowawczych. Należy jednak zadbać, aby rodzina nie przerzucała swoich zobowiązań na szeroko pojęte instytucje. Szczególną troską Kościoła należy objąć dzieci wychowywane w małżeństwach mieszanych, poprzez zwrócenie szczególnej uwagi nupturientów na zobowiązania w zakresie wychowania potomstwa. Niewątpliwie religijność samych rodziców przekłada się na późniejsze życie ich dzieci. Obowiązkiem rodziców jest wprowadzić dziecko w życie sakramentalne. Mogłoby się wydawać, że ustawodawca uznał prawo dziecka do wychowania za rzecz naturalną i zrezygnował z uregulowania tej kwestii w postaci przepisu prawa. Liczba kanonów dotyczących dzieci wskazuje, iż ustawodawcy problem ten nie pozostał obcy. Najlepsze zabezpieczenie prawa dziecka do wychowania powinno być przedmiotem największej troski rodziców, co stanowi wystarczającą ochronę jego interesów. Można by postulować, aby w ustawodawstwie kościelnym pojawił się zapis odnośnie do prawa dziecka do wychowania i sankcji za naruszenie tego prawa, co gwarantowałoby efektywną ochronę.

\section{PIŚMIENNICTWO}

Adamowicz, Leszek. 1998. „Przynależność do Kościoła sui iuris według obowiązującego prawa kościelnego.” Roczniki Nauk Prawych 8:129-46.

Adamowicz, Leszek. 1999. Wprowadzenie do prawa o sakramentach świętych według Kodeksu Prawa Kanonicznego oraz Kodeksu Kanonów Kościołów Wschodnich. Lublin: Wydawnictwo Muzyczne Polihymnia. 
Adamowicz, Leszek. 2014. „Bonum prolis w małżeństwach mieszanych.” W $W$ orbicie zasady „odpowiedzialnego rodzicielstwa” Adekwatne rozumienie pojęcia bonum prolis wyzwaniem dla współczesnej kanonistyki, red. Andrzej Pastwa, 65-80. Katowice: Wydawnictwo Księgarnia Św. Jacka.

Adamowicz, Leszek. 2015. „Przynależność kościelna i obrządkowa dziecka.” W Prawa dziecka: perspektywa Kościoła, red. Piotr Kroczek, 9-29. Kraków: Uniwersytet Papieski Jana Pawła II. Wydawnictwo Naukowe.

Cader, Stanisław. 2004. Rodzina środowiskiem wychowawczym w świetle nauczania Jana Pawła II. Kraków: Wydawnictwo Naukowe PAT.

Cymbała, Jan. 2002. Istotne obowiązki małżeńskie i przyczyny niezdolności do ich podjęcia w wyrokach Roty Rzymskiej z lat 1983-1992 wydanych na podstawie kan. 1095 nr 3 Kodeksu Prawa Kanonicznego opublikowanych w „Decisiones”. Olsztyn: Wydawnictwo Wyższego Seminarium Duchownego Metropolii Warmińskiej „Hosianum”.

Czujek, Marcin. 2015. „Prawa dziecka w kontekście obowiązków małżeńskich. Spojrzenie kanoniczno-cywilne.” Studia Redemptorystowskie 13:427-42.

Fiałkowski, Marek. 2011. „Katolickie szkoły i uniwersytety ośrodkami formacji katolików świeckich.” Roczniki Pastoralno-Katechetyczne 3 (58): 375-89.

Góralski, Wojciech. 2000. Kanoniczne prawo małżeńskie. Warszawa: Polskie Wydawnictwo Prawnicze IURIS.

Krajczyński, Jan. 2005. „Wychowanie dziecka w prawie kanonicznym, polskim i wspólnotowym." Studia z Prawa Wyznaniowego 8:163-89.

Kroczek, Piotr. 2013. Wychowanie. Optyka prawa polskiego i kanonicznego. Kraków: Uniwersytet Papieski Jana Pawła II w Krakowie. Wydawnictwo Naukowe.

Krukowski, Józef. 2006. „Ochrona prawa rodziców do moralnego i religijnego wychowania dzieci. Wprowadzenie do problematyki.” Biuletyn Stowarzyszenia Kanonistów Polskich 19:48-62.

Pastwa, Andrzej. 2014. „Niezdolność do wypełnienia zadań rodzicielskich i wychowawczych.” W $W$ orbicie zasady „odpowiedzialnego rodzicielstwa”. Adekwatne rozumienie pojęcia bonum prolis wyzwaniem dla współczesnej kanonistyki, red. Andrzej Pastwa, 48-64. Katowice: Wydawnictwo Księgarnia Św. Jacka.

Pawluk, Tadeusz. 1984. Prawo kanoniczne według Kodeksu Jana Pawła II. T. 3: Prawo małżeńskie. Olsztyn: Warmińskie Wydawnictwo Diecezjalne.

Pawluk, Tadeusz. 2002. Prawo kanoniczne według Kodeksu Jana Pawła II. T. 1: Zagadnienia wstępne i normy ogólne. Olsztyn: Warmińskie Wydawnictwo Diecezjalne.

Paździor, Stanisław. 1999. Przyczyny psychiczne niezdolności osoby do zawarcia małżeństwa w świetle kan. 1095. Sandomierz-Lublin: Wydawnictwo Diecezjalne Sandomierz.

Stala, Józef. 2006. „Katecheza rodzinna. Próba teologicznego zarysu zagadnienia.” W Rodzina bezcenny dar i zadanie, red. Józef Stala, i Elżbieta Osewska, 182-220. Radom: Polwen Polskie Wydawnictwo Encyklopedyczne.

Stawniak, Henryk. 1993. „Udział małżonków-rodziców w kościelnej posłudze uświęcania." Prawo Kanoniczne 36, nr 3-4:121-36.

Syryjczyk, Jerzy. 1987. „Troska Kościoła o katolickie wychowanie dzieci w kanonicznym prawie karnym." Prawo Kanoniczne 30, nr 3-4:223-25.

Sztafrowski, Edward. 1985. Chrześcijańskie małżeństwo: Pomoce prawno-pastoralne. Warszawa: Akademia Teologii Katolickiej.

Sztychmiler, Ryszard. 1998. „Obowiązki małżeńskie - istotne i nieistotne.” Ius Matrimoniale 3:115-34. 
Świaczny, Seweryn, i Anna Pustelnik. 2004. „Prawa i obowiązki w zakresie wychowania w ujęciu Kodeksu Prawa Kanonicznego. Współpraca rodziców i szkoły oraz jej formy." Prawo Kanoniczne 47, nr 1-2:25-59.

Wilk, Józef, i Robert Bieleń. 2006. „Pedagogika rodziny - zagadnienia wybrane.” W Rodzina bezcenny dar i zadanie, red. Józef Stala, i Elżbieta Osewska, 423-79. Radom: Polwen Polskie Wydawnictwo Encyklopedyczne.

Zubert, Bronisław. 1996 „Chrzest dziecka wbrew woli rodziców.” Prawo Kanoniczne 39, nr 3-4:34-64.

Prawo dziecka do wychowania w prawodawstwie Kościoła łacińskiego z elementami prawa polskiego

Streszczenie

Prawo dziecka do wychowania stanowi szczególną troskę Kościoła. Wskazuje na to chociażby liczba kanonów odnoszących się do dzieci. Dziecko jest podmiotem wychowania. Posiada niezbywalne prawo do wychowania $\mathrm{z}$ uwagi na przyrodzoną godność. Rodzice, ponieważ dali dzieciom życie, mają najcięższy obowiązek jego wychowania. W małżeństwach mieszanych należy uświadamiać nupturientów o zobowiązaniach $\mathrm{w}$ zakresie katolickiego wychowania potomstwa. Rodzice powinni wprowadzić dzieci w życie sakramentalne. Religijność rodziców przekłada się na późniejszy rozwój dziecka oraz jego funkcjonowanie w społeczeństwie. Prawo dziecka do wychowania zabezpieczają instytucje, których zadaniem jest wspieranie rodziców i wzmocnienie ochrony prawnej w tym zakresie. Rodzice nie powinni swoich obowiązków względem potomstwa przerzucać na instytucje i inne wspólnoty. Jest oczywiste, że ustawodawca prawo dziecka uważa za rzecz na tyle naturalną, że zrezygnował $\mathrm{z}$ uregulowania tego zagadnienia $\mathrm{w}$ formie przepisu.

Słowa kluczowe: prawa dziecka; obowiązki rodziców; wychowanie potomstwa; ochrona praw dziecka

\author{
Right of a Child to be Raised \\ in Latin Church Legislation and Polish Law
}

\title{
Summary
}

The child's right to education is an open concern of the Church. It indicates at least the number of canons related with children. The child is the object of upbringing. $\mathrm{He}$ has an inalienable right to education, observing his inherent dignity. Parents, since they have given life to their children, have a most grave obligation and possess the right to educate them. In mixed marriages, nupturients should be made aware of their obligations in the field of Catholic applied education. Parents must share their sacramental life. Parental religiosity translates into the later development of the child 
and his functioning in society. The child's right to secure parenting that is available to parents and protection in this regard. Parents should not shift their religious responsibilities to institutions and other communities. It is obvious that the law is the duty of a child, that it is natural that he gave up regulating this issue in the form of a provision.

Key words: children's rights; parent's responsibility; education of children; protection of children's rights

Information about Author: MARTYNA PERETA, J.C.L. - Ph.D. student, Department of Church Procedural Law, Marriage Law and Penal Law and the Eastern Catholic Churches, Institute of Canon Law, Faculty of Law, Canon Law and Administration at the John Paul II Catholic University of Lublin; Al. Racławickie 14, 20-950 Lublin, Poland; e-mail: martynapereta@gmail.com; https://orcid.org/0000-0003-2501-6458 